УДК 371.3::811.111’243

УДК 374.7

\title{
Горана 3. Билић Пријић
}

Филозофски факултет Универзитета у Новом Саду

Докторанд на Методици наставе

gorana.bilic86@gmail.com

\section{ОДНОС АНДРАГОГИЈЕ И ПЕДАГОГИЈЕ У УЛОГАМА НАСТАВНИКА У АНДРАГОШКОЈ НАСТАВИ ЕНГЛЕСКОГ ЈЕЗИКА ${ }^{1}$}

\begin{abstract}
Сажетак
Зачеци андрагогије и дидактике страних језика настали су као део универзалне и неиздиференциране педагошке теоријске мисли о васпитању и образовању. Средином 20. века јавила се борба да се андрагошка теоријска мисао и пракса издиференцирају у односу на општу педагошку мисао. Данас фокус више није на диференцијацији и супротстављању андрагогије и педагогије већ на њиховом преплитању и развоју кроз међусобне утицаје. Андрагогија и педагогија посматрају се као две тачке једног континуума. У развоју улога наставника у андрагошкој настави енглеског језика преплићу се андрагошки и педагошки утицаји, са приметном тенденцијом да настава и улоге наставника временом постају све више андрагошки. У овом раду покушаћемо да прикажемо преплитање утицаја педагошке и андрагошке теоријске мисли на улогу наставника у андрагошкој настави кроз историју, са фокусом на улогу наставника у андрагошкој настави енглеског језика данас.
\end{abstract}

Кључне речи: андрагогија, педагогија, дидактика страних језика, улога наставника у андрагошкој настави, енглески језик

\section{1. УВОД}

Андрагогија и теорија наставе страних језика научно су засноване тек у 20. веку па је научна основа андрагошке наставе језика још увек прилич-

1 Овај рад је проистекао из рада на пројекту Квалитет образовног система Србије у европској перспективи који финансира Министарство просвете, науке и технолошког развоја Републике Србије. 
но неразвијена (Самолвчев 1993) и великим делом ослања се на педагогију. Прожимање науке о настави страних језика и андрагогије на самом је почетку. То свакако отежава посао наставника у андрагошкој настави енглеског језика. Ипак, чињеница је да су знања која постоје о настави језика, о учењу одраслих и о андрагошкој настави данас најсистематичнија и највише се примењују у односу на претходне периоде, када андрагогија и настава језика нису постојале као науке, већ су наставници наставу углавном интуитивно прилагођавали одраслима, на основу претпоставки и сопственог искуства (Richards and Rogers 1997). У овом раду приказаћемо историјски развој односа педагогије и андрагогије са фокусом на данашње стање ствари, а затим ћемо упоредити улоге наставника у андрагошкој и педагошкој настави и у том светлу сагледати улогу наставника у андрагошкој настави енглеског језика данас.

\section{2. ПОВЕЗАНОСТ ПЕДАГОГИЈЕ И АНДРАГОГИЈЕ}

Педагошка мисао је дуго била универзална и неиздиференцирана теоријска мисао о васпитању и образовању. У ренесансној епохи дошло је до издвајања педагошке мисли из опште филозофске мисли а тек у 19. веку догодила се унутрашња диференцијација педагогије. Теоријска мисао о образовању одраслих одувек се ослањала на општу педагошку мисао ,,jep је из ње произашла и с њом се преплиће до данашњег дана” (Самолвчев 1993: 6).

Педагогију као науку о васпитању младих научно је засновао Хербарт. Пре њега, Коменски је схватао дидактику као universale omnes omnia, што значи „учење свих свему” (исто, 18). Хербарт је и сам приметио да је схватањем педагогије као науке о васпитању младих остало једно непокривено поље - поље образовања одраслих. Хербарт је тридесетих година 19. века користио термин андрагогија за науку о васпитању „пунолетног човека” у својим покушајима да укаже на потребу за научним утемељењем нове области која би се бавила образовањем одраслих. Ова Хербартова идеја остварена је тек средином 20. века, дакле више од века касније (Исто). До тада je „педагогија одраслих" или ,андрагогија” или ,адултна педагогија” постојала у склопу педагогије, па је педагогија имала велики утицај на област образовања одраслих. С обзиром да реч педагогија потиче од грчких речи nаид (дете) и агогус (онај који води), педагогија образовања одраслих је наизглед контрадикторна фраза, али, како каже Ноулс (Knowles 1984), ако се боље размисли, одрасли се у образовању често заиста третирају као деца па ова фраза и има смисла. 
Ноулс (Knowles 1984) описује традиционалну педагошку наставу као наставу у којој наставник има пуну одговорност за доношење одлука о томе шта ће се учити, како ће се учити, када ће се учити, као и да ли је нешто научено. То је образовање у чијем је центру наставник а ученик има потчињену улогу праћења наставникових инструкција. Важно је нагласити да када говори о „педагогошком моделу”, Nouls (Исто) у ствари мисли на остатке традиционалне педагошке теорије и праксе које пре свега карактерише пасивизација ученика. Он не говори о педагогији уопште, већ се фокусира на негативне појаве у педагошкој теорији и пракси које се данас сматрају непожељним и у образовању деце и које он користи као полазну тачку за побољшање андрагошке наставе.

Овде ћемо навести претпоставке о ученицима на којима су засновани модели наставе које Ноулс (Knowles 1984) назива педагошким и андрагошким моделом наставе. Треба нагласити да се претпоставке о младим ученицима које он излаже не могу сматрати инхерентним особинама младих ученика, већ пре последицом трансмисивне педагогије. Ове претпоставке, дакле, имају већу вредност као претпоставке о карактеристикама одраслих ученика него као претпоставке о разликама између одраслих ученика и деце (Ољача 1997). Те претпоставке су, према Ноулсу (Knowles 1984):

- Потреба да се зна:

Педагошки модел: Ученици треба да знају да морају да науче оно што наставник предаје ако желе да положе испите и напредују у виши разред, али не морају да знају како ће оно што уче применити у стварном животу.

Андрагошки модел: Одрасли уче под притиском текућих животних проблема. Они дакле уче како би непосредно применили научено.

- Самоконцепт ученика:

Педагошки модел: Наставник на ученика гледа као на зависну личност тако да то на крају постаје учеников самоконцепт. Непримереност самоконцепта ученика као зависне личности у андрагошкој настави енглеског језика долази до изражаја приликом примене висококонтролисаних метода у настави енглеског језика, нпр. аудио-лингвалног метода, у којем је главна улога ученика да имитира модел који даје наставник. Наиме, према Ларсен-Фримановој (Larsen-Freeman 2000), ученици тачно формулишу реченице на часу, али нису у стању да учине исто и када се нађу у ситуацијама ван учионице када треба да комуницирају са другима. Висока несамосталност ученика у настави доводи до несамосталности и у ситуацијама у којима се од ученика очекује да примене оно што су у настави научили.

Андрагошки модел: Одрасли виде себе као одговорне, независне и самоусмерене особе. Они очекују да наставници уважавају њихову способност 
да доносе одлуке и да преузму одговорност у процесу учења тако што ће са наставником учествовати у утврђивању потреба за учењем, планирању, спровођењу и евалуацији учења.

- Улога искуства у учењу:

Педагошки модел: Учениково искуство нема велику вредност. Више се вреднује наставниково искуство.

Андрагошки модел: Искуство одраслих ученика постаје значајна основа на коју се надограђује ново учење. Искуство ученика у андрагошкој настави енглеског језика може утицати на избор садржаја, али оно што је такође важно јесте да наставник разуме афективну страну учења, на пример да саслуша и разуме осећања ученика током учења језика (нпр. фрустрације, страх, мањак или раст самопоуздања итд.). Учење језика мора укључивати све аспекте искуства коришћења језика у реалним ситуацијама. На пример, наставник треба ученицима да помогне у стицању комуникативних компетенција које представљају врло важан део учења језика. Значај искуства лежи у чињеници да оно обезбеђује основу идентитета одраслих људи и да одрасле особе дефинишу себе на основу свог искуства (Knowles et al. 2005).

- Спремност за учење:

Педагошки модел: Ученици постају спремни да уче оно што им наставник каже да морају да науче ако желе да положе тестове и пређу на виши ниво на образовној лествици.

Савићевић (2007) сматра да је дечија спремност за учење резултат биолошког развоја и академског притиска.

Андрагошки модел: Начин на који се секвенцира учење одраслих треба да буде у складу са социјалним улогама и за њих везаним развојним задацима ученика (животним задацима као што су завршавање факултета и улазак у свет рада, заснивање породице, губитак или промена посла, одлазак у пензију итд.), а не само под утицајем логике наставног предмета или образовне установе.

- Оријентација у учењу:

Педагошки модел: У центру је предмет, учење значи усвајање садржаја о неком предмету. Учење младих ученика карактерише принцип одложене примене наученог.

Андрагошки модел: Одрасли уче како би непосредно применили на-

учено. „У активности учења одрасли улазе усмерени на проблем, а знатно мање на предмет" (Савићевић 2007: 152-155).

- Мотивација:

Педагошки модел: Мотивација је спољашња. 
Андрагошки модел: Мотивација је унутрашња. Иако одрасле мотивишу спољашњи фактори, нпр. унапређења, већа плата и притисак других, унутрашња мотивација да реше одређене животне проблеме, нпр. да више уживају у свом послу, да имају више самопоуздања, већи квалитет живота, као и да се самоостваре, представља најснажнији вид мотивације код одраслих ученика.

Ноулс (Knowles 1984) објашњава зашто је модел који он назива педагошким био примењиван у образовању одраслих. Он каже да је педагошки модел скуп претпоставки који је настао између 7. и 12. века у манастирским школама у Европи, на основу искуства у поучавању дечака основним вештинама. У наредним вековима настале су секуларне школе док државне школе настају у 19. веку, са педагошким моделом као јединим који је постојао. У систематском образовању одраслих, после 1. светског рата, коришћен је педагошки модел као једини модел који су наставници имали у то време. Резултат је био тај да су до недавно одрасли били поучавани на исти начин као и деца (Исто). Савићевић (2007) ову појаву назива инфантилизацијом образовне политике и инфантилним приступом образовању и учењу одраслих.

Принципи Ноулсове андрагогије, према Брукфилду (Brookfield 1986), нису засновани на јединственим одликама учења одраслих и овај приступ не може се јасно одвојити од педагогије. Ноулс дефинише андрагогију као „вештину и науку помагања одраслима у учењу” (Knowles 1970: 38). Када је Ноулс први пут увео андрагогију у образовање одраслих шездесетих година, представио ју је као антитезу педагогије јер се заснивала на учењу одраслих које се, по њему, значајно разликовало од учења деце. Између 1970. и 1980. Ноулс је променио свој став да је андрагогија супротна педагогији, пропагирајући идеју да су педагогија и андрагогија на континууму који се протеже од учења које усмерава наставник до учења које усмерава ученик. Дакле, андрагогију сматра општом теоријом инструкције, коју могу да користе сви наставници у наставном раду са ученицима свих узраста (Knowles 1984).

Ноулс (Knowles 1984), дакле, не сматра да је андрагогија супериорна у односу на педагогију, нити да је применљива само на одрасле. Андрагогија добија значење универзалне теорије учења и поучавања. Ноулсов став је да се неке педагошке претпоставке могу применити на одрасле, а андрагошке на децу. Он верује да примена једних или других зависи од појединачних околности. На пример, одрасли ученик који нема никакво предзнање о некој теми више ће се ослањати на наставника и очекиваће више усмеравања од њега, док деца могу бити у многим ситуацијама самоусмерена (Исто). У својој критици андрагогије Елајас (Elias 1979) напомиње да су и Ериксон и Пијаже нашли елементе самоусмерености у учењу деце. 
Брукфилд (Brookfield 1986) подржава идеју Ноулса (Knowles 1984) који каже да су педагогија и андрагогија две тачке једног континуума и да коришћење искуства и интересовања ученика у настави није ништа ново, да се тај принцип већ примењује у настави деце. Брукфилд закључује да треба користити оне методе и приступе који одговарају одређеној групи ученика и одређеном садржају и ситуацији (Исто).

\section{3. УЛОГА НАСТАВНИКА У АНДРАГОШКОЈ НАСТАВИ ЕНГЛЕСКОГ ЈЕЗИКА}

Концепција наставе одраслима, укључујући андрагошку наставу енглеског језика, прешла је пут од поучавања као преношења знања, где је главна улога ученика пасивно репродуковање знања која му преноси наставник, до активног учења и наставе. У складу с тим се променила и традиционална улога наставника као особе која поучава у наставника као помагача у учењу (Савићевић 2007). Када говоримо о улози наставника као некога ко поучава, важно је истовремено сагледати и улогу ученика у том процесу. Поучавање само по себи није лоша и непожељна активност. Оно што се сматра непожељним јесте да поучавање подразумева улогу ученика која се састоји у механичком усвајању и репродуковању знања која му наставник преноси.

Концепција поучавања потиче из логичког позитивизма и веровања да се знања преносе. Улога наставника је да изабере најбоље методе којима ће пренети знања. Супротно овом становишту је схватање учења као процеса интеракције. „Ученици су у интеракцији са помагачима у учењу и другим ученицима, као и са садржајима образовања, изворима, идејама, вредностима и основама знања. На тај начин учење одраслих постаје стваралачка активност" (Савићевић 2007: 253).

Андрагошка и педагошка теорија и пракса заснивају се на различитим филозофијама. Андрагошка теорија и пракса црпе основне принципе из филозофије прогресивизма, према којој образовање није припрема за живот већ сам живот. Улога наставника је да само предводи учење и саветује ученика. Наставник није једини извор знања. „Одговорност наставника је да организује, стимулише, подстиче и процењује комплексни процес образовања. Наставник обезбеђује средину погодну за учење" (Савићевић 2002). Наставници, уместо да ученицима преносе информације које су други бирали и обликовали у виду наставних програма и за које се сматра да „образована” особа треба да их зна, треба да дозволе ученицима да уче оно што их занима 
или они сматрају да им је корисно. Другим речима, наставници помажу ученицима да остваре своје интересе (Исто).

Андрагошка теорија и пракса ослањају се и на филозофију хуманизма. Према овој филозофији, задатак образовања је самоостваривање, остваривање потенцијала појединца, при чему он следи властите интересе а не спољне смернице (Исто). Према филозофији хуманизма, конвенционално образовање, у којем доминира трансмисивна педагогија, није адекватно за одрасле јер се схвата као наметање. Учење треба да буде усмерено на ученика, при чему наставник нема директивну улогу. Наставник помаже ученицима и даје им слободу да напредују у складу са својим интересима и могућностима. Ову филозофију одликује вера у ученика која је основа за давање слободе и одговорности ученицима (Исто).

Модел који Ноулс (Knowles 1984) назива педагошким ослања се на филозофију либералног образовања, која претпоставља супериорност наставника у процесу образовања и учења. Наставник преноси знања на ученике и намеће своја схватања без обзира на то да ли та схватања имају значење за њих. Ову појаву Пауло Фрер (Paulo Freire 2000) означио је банковном концепцијом образовања, чија је суштина учениково пасивно акумулирање чињеница које им наставник преноси. Либерална филозофија образовања знање види као апсолутно, тј. фиксирано и непроменљиво и изван контекста. Либерални филозофи сматрају да поседују критеријуме да процене које знање је корисно за ученике.

Андрагошки модел наставе сматра се процесним моделом (Knowles 1984), а насупрот њега стоји садржајни модел. Разлика је следећа: у садржајном моделу наставник (или нека друга особа одговорна за осмишљавање и спровођење курикулума) унапред одлучује које знање или вештине треба пренети, организује садржај у логичне целине, бира најефикасније начине преношења садржаја (предавања, читање, лабораторијске вежбе, филмови, аудио записи итд.), а затим развија план за презентовање ове целине у одређеном редоследу. У процесном моделу наставник (фацилитатор, консултант, агенс промена) унапред припрема скуп процедура којима укључује ученике (и друге релевантне стране) у процес наставе (Knowles 1984). „Разлика међу њима није да се један бави садржајем, а други не. Разлика је у томе што се садржајни модел фокусира на преношење информација и вештина док се процесни модел фокусира на обезбеђивање процедура и извора који би помогли ученицима да стекну знања и вештине” (Исто: 85).

Ако се анализирају различите методе и приступи у настави енглеског језика, може се уочити да су андрагошки принципи присутни у већој или мањој мери у готово сваком од њих. Настава језика коју можемо означити 
андрагошком има следеће особине: хуманистичку филозофију, слободу ученика (и одговорност коју та слобода подразумева) да активно и креативно учи откривајући језичка правила кроз активну употребу језика као средства комуникације и слободу ученика да са наставником учествује у планирању наставе и тако је прилагођава индивидуалним потребама.

Улоге наставника у методама и приступима наставе енглеског језика су више или мање андрагошке.

Методе које не садрже андрагошке елементе називамо неандрагошким. То су:

- граматичко-преводни метод, бихејвиористичке методе

У овим методама комуникација је углавном једнострана, усмерена од наставника ка ученику. Активност ученика састоји се од механичког учења и меморисања правила. Нема простора за креативност ученика и настава се не прилагођава њиховим индивидуалним потребама. Може се уочити правило повезаности понашања ученика и наставника: када наставник активно и креативно размишља о томе како да унапреди наставу, тј. како да помогне ученицима да што боље уче, када он није обичан посредник између уџбеника или метода с једне стране и ученика с друге, он се фокусира на ученике и наставу прилагођава њима. Природан резултат оваквих активности је да ученици добијају више слободе и подстицаја да буду креативни и активни субјекти у учењу и настави. У граматичко-преводном методу настава је високо контролисана - настава се организује око уџбеника који диктира шта ће се вежбати и како, уџбеник контролише понашање наставника, а наставник понашање ученика.

Високо контролисане методе остављају мањи простор за примену андрагошких принципа, али ипак садрже неке андрагошке елементе и њих ћемо означити као делимично андрагошке. То су:

- директни метод, природни метод, орални приступ, ситуациона настава, настава заснована на когнитивној теорији, тотални физички одговор, неми начин, кооперативно учење језика

У овим методама ученици преузимају улогу партнера у настави, али и даље наставник управља процесом наставе и учења, односно преузима највећу одговорност за исходе учења. Између наставника и ученика и између самих ученика постоји интеракција, али њом у великој мери управља наставник (Larsen-Freeman 2000). У литератури се улога наставника у овим методама често пореди са улогом диригента а ученици са члановима оркестра.

Оне методе и приступе који имају хуманистичку филозофску оријентацију и остварују принцип слободе ученика и у процесу усвајања знања и у планирању наставе, означавамо као високоандрагошке. То су следеће методе: 
• учење језика у заједници, комуникативна настава језика, природни приступ

У овим приступима улога наставника је да олакшава комуникацију међу ученицима. Наставник обезбеђује ситуације које ће подстаћи комуникацију. Он је саветник, одговара на питања и надгледа рад ученика, бележи грешке којима касније посвећује пажњу у активностима које су фокусиране на тачност у производњи језика. У овим приступима ученици су у центру, они преузимају одговорност за сопствено учење тако што постају активни не само у процесу учења, већ и у доношењу одлука које се тичу обликовања саме наставе. Читава настава се потчињава ученику и његовим потребама (Larsen-Freeman 2000).

Можемо приметити да су временом приступи и методе постајали све више андрагошки, од најстаријег, граматичко-преводног метода као једног од представника неандрагошких метода, до комуникативног приступа који доминира у савременој настави језика и који омогућава највиши степен примене андрагошких принципа у односу на претходне приступе. Исто важи и за улогу наставника - временом је постајала све више андрагошка, тј. наставник је све више преузимао улогу фацилитатора - прво фацилитатора у ужем смислу, а онда све више и фацилитатора у ширем смислу. Фацилитатор у ужем смислу помаже ученицима да усвоје знања тако што интервенише у самом процесу учења и даје ученику активну улогу у усвајању знања, али сам одлучује о томе шта и како ће се учити, док фацилитатор у ширем смислу помаже ученицима и у планирању процеса наставе и у самом процесу учења, тј. подстиче аутодидаксију.

\section{4. ТЕНДЕНЦИЈЕ У АНДРАГОШКОЈ \\ НАСТАВИ ЕНГЛЕСКОГ ЈЕЗИКА И УЛОЗИ НАСТАВНИКА}

Андрагогија, андрагошка настава енглеског језика и улога наставника у њој прилагођавају се потребама савременог света. Брзе промене су резултат технолошког развоја и глобализације које одликују брза размена информација, стварање нових информација и њихово брзо застаревање. Основни циљ образовања које иде у корак са савременим светом више није преношење знања, јер знање брзо застарева, већ развијање способности ученика да из мноштва информација изаберу оне које су им заиста потребне. Зато андрагогија пропагира слободу и флексибилност као основне одлике андрагошке наставе (Савићевић 2002). Такође, индивидуализација је неизоставан елемент и савременог света и процеса образовања. Тежи се задовољавању 
индивидуалних потреба појединца тако што му се нуди велики избор и слобода да бира. Ова тенденција одражава се и у савременом андрагошком образовању у којем је циљ наставе да ученик задовољи индивидуалне образовне потребе на индивидуализован начин.

Наставник мора прилагођавати наставу новонасталим околностима и потребама у спољашњем свету, потребама појединачних ученика и потребама и околностима у самом процесу наставе. Конкретно, у андрагошкој настави енглеског језика, то значи да наставник треба да прати захтеве који долазе из спољног света, на пример критеријуме међународних испита енглеског језика или потребе које намеће тржиште рада у процесима преквалификације радника, затим нове начине и форме комуникације које доноси развој информационих технологија итд.

У току наставе јављају се нове потребе и нове околности које од наставника захтевају да мења циљеве и приоритете које је поставио на почетку наставе. То подразумева континуирано откривање потреба ученика, најбоље директним укључивањем ученика у одређивање својих потреба (Brookfield 1991). Наставник на основу свог знања, искуства и прикупљених информација о потребама ученика, помаже ученицима да идентификовањем и задовољавањем својих образовних потреба постану функционални чланови савременог друштва. У настави енглеског језика то се може постићи применом уговора о учењу. Уговори о учењу представљају механизам помоћу кога ученици и наставници планирају и остварују самоусмерено учење (Brookfield 1986). Уговори садрже циљеве учења, релевантне изворе, одређене активности и процедуре евалуације (Исто). Задатак наставника је да помогне ученицима да науче како да саставе уговор о учењу, затим да им помогне у самом састављању уговора и да се постара да се ученици при креирању уговора фокусирају на реалистичне циљеве и изводљиве активности. У одређивању потреба може се користити и вежба критичног инцидента у којој се од ученика тражи да опишу неку ситуацију у којој су имали проблем, на пример нису успели да успешно комуницирају на енглеском језику, а затим се анализирају потребе и одређују циљеви, прави се инвентар потреба, ученици предлажу активности и коментаришу предлоге наставника (Исто).

\section{5. ЗАКљУЧАК}

Можемо да закључимо да фокус више није на раздвајању андрагогије и педагогије и на њиховом супротстављању. Андрагошка и педагошка теорија и пракса се због своје сложености и међусобне повезаности томе опиру. 
Андрагогија и педагогија су до данашњег дана испреплетане и развијају се заједно, међусобно утичући једна на другу. Ова сложеност огледа се и у улози наставника у андрагошкој настави енглеског језика, који није више само особа која зна енглески језик или особа која зна енглески језик и познаје педагошке и андрагошке принципе наставе језика. Он мора да стиче андрагошка, педагошка, лингвистичка, али и социолошка и психолошка знања у ритму промена друштвених околности које га окружују и промена у корпусу знања. Спремност наставника да се прилагођава променљивим околностима и потребама самих ученика јесте суштина андрагошке наставе. Такође, оно чему наставник увек треба да тежи је да учини ученике самоусмереним, док настава не постане високоандрагошка тј. док се ученици не оспособе за доношење одлука о садржају и начину наставе и тако је индивидуализују у највећој могућој мери. На тај начин ће и њихово учење бити релевантније за задовољавање индивидуалних потреба и ученици ће постати задовољнији и упешнији и као појединци и као чланови друштва, што је и далекосежни циљ андрагошке наставе уопште и андрагошке наставе енглеског језика.

\section{ЛИТЕРАТУРА}

Brookfield, S. D. (1986). Understanding and facilitating adult learning: A comprehensive analysis of principles and effective practices. San Francisco: Jossey Bass.

Brookfield, S. D. (1991). Grounding teaching in learning. In: Galbraith, M. W. (ed.) (1991). Facilitating adult learning: A transactional process (p. 33-56). Molabor: Krieger.

Elias, J. L. (1979). Andragogy revisited. Adult Education Quarterly, 29(4), 252256.

Freire, P. (2000). Pedagogy of the oppressed. New York: Continuum International Publishing Group.

Knowles, M. S. (1970). Andragogy: An emerging technology for adult learning. New York: Association Press.

Knowles, M. S. (1984). The adult learner: A neglected species ( ${ }^{\text {rd }}$ edition). Houston: Gulf Publishing.

Knowles, M. S., Holton III, E. F., \& Swanson, R. A. (2005). The adult learner: The definitive classic in adult education and human resource development. Burlington: Elsevier.

Larsen-Freeman, D. (2000). Techniques and principles in language teaching. Oxford: Oxford University Press. 
Ољача, М. (1997). Андрагогија: психолошке основе учења одраслих. Нови Сад: Филозофски факултет.

Richards, J. C., \& Rogers, T. S. (1997). Approaches and methods in language teaching $\left(13^{\text {th }}\right.$ edition). Cambridge: Cambridge University Press.

Самолвчев, Б. (1993). Историјски корени и токови андрагошке теорије. Београд: Интер ЈУ Прес.

Савићевић, Д. (2002). Филозофски основи андрагогије. Београд: Завод за уџбенике и наставна средства.

Савићевић, Д. (2007). Особености учења одраслих. Београд: Завод за уџбенике и наставна средства.

\title{
Gorana Z. Bilić Prijić
}

\author{
THE RELATIONSHIP BETWEEN ANDRAGOGY AND PEDAGOGY \\ IN THE ROLES OF THE ANDRAGOGICAL ENGLISH LANGUAGE TEACHER
}

\section{Summary}

The beginnings of andragogy and the science of foreign language teaching emerged from the universal and undifferentiated pedagogical theoretical thought about education. Mid $20^{\text {th }}$ century saw a struggle to differentiate the andragogical theory and practice from the general pedagogical thought. Today it seems that the focus is no longer on differentiating and opposing andragogy and pedagogy, but rather on their connections and the development through their mutual influence. Andragogy and pedagogy are seen as two points on the same continuum. In the development of the roles of the andragogical English language teacher, the andragogical and theoretical influences are interwoven, with a clear tendency for teaching and the role of the teacher to become increasingly andragogical. The aim of this paper is to show how the pedagogical and andragogical theoretical thought affects the role of the andragogical teacher of the English language through history, with the focus on the roles of the andragogical English language teacher today.

Key words: andragogy, pedagogy, foreign language teaching didactics, role of the andragogical English language teacher. 